\title{
GROUP COLONY FOUNDATION IN POLISTES ANNULARIS (HYMENOPTERA: VESPIDAE)*
}

\author{
By Joan E. Strassmann \\ Department of Ecology and Evolutionary Biology \\ Rice University, P.O. Box 1892, Houston TX 77251
}

Foundresses of primitively eusocial insects have been the focus of many studies of the evolution of altruism because these females have a solitary or a social option. Comparing the costs and benefits of these options is one way of gaining insight into the circumstances that originally increased the fitness of individuals pursuing social options. Previous studies have indicated that altruists in small groups may pass on more genes than do solitary individuals (Noonan 1981; Gibo 1978; Metcalf \& Whitt 1977). Variation around an optimum number of foundresses is usually ascribed to a shortage of potential nestmates, especially at locations far from the natal nest site since only natal nestmates begin nests together (Noonan 1981). The current study differs from previous studies because foundress associations are especially large in Polistes annularis, making it likely that benefits to group nesting will be pronounced. It also has several advantages because of the nature of the study site. It is an exposed limestone cliff where all nests including small ones are readily visible, so the complete cohort of sibling nests can be observed, and reproductive success can be assessed without missing any nests. This cliff is a natural site where costs and benefits are unlikely to have been changed because of human alterations to the environment. Since I followed nesting success for several years it is unlikely that the aberrant climate of one year will unduly influence the results.

I expect that nests with multiple foundresses on them will suffer lower rates of predation, parasitism and usurpation, since they will be better defended. Nests with multiple foundresses are also less likely to fail because all adults die, since there are multiple females tending the brood on these nests. The constraints of location and available females may limit foundress association size. Since nests are begun by females emerging from the same natal nest, the number of such females available will put an upper limit on foundress associations. In general females that do not disperse far from

*Manuscript received by the editor August 20, 1989. 
the natal nest congregate in larger groups to start nests (Klahn 1979). Group size is predicted to decrease with increasing distance to natal nest, and to be greatest on re-uses of the natal nest (Strassmann 1979).

\section{METHODS}

I studied a dense population of Polistes annularis on a cliff over a reservoir west of Austin, Texas (Strassmann 1979; Queller \& Strassmann 1988). I located nests and numbered them as they were initiated and marked foundresses if they had not been marked the previous autumn, from 1976-1980. Nests were censused every 3 days before worker emergence and every 4 to 10 days afterwards. At each census I noted number of females, the identity of marked females and nest condition. Females did not move from one nest to another (Strassmann 1983). But sometimes it was difficult to see all the females on the nest because some were clumped on the back of the nest. Therefore I did not use one census date to determine foundress number in spring. Instead, foundress number was determined to be the maximum number simultaneoulsy on the nest during April, before workers emerged (Queller \& Strassmann 1988). Queens were determined behaviorally on many of the nests by their extended presence on the face of the nest, egg laying, gaster vibrating and chewing on other females (Strassmann 1981). Because I wanted to follow foundresses from their natal nests in autumn to new nests the following spring, I marked females on the thorax with a unique color for each nest in autumn. This allowed their springtime assignment to new nests. In this population distance from natal nests to new springtime nests is easily measured because it is essentially a two-dimensional habitat.

\section{RESULTS}

Foundress numbers varied from 1 to 28 (Fig. 1). Average number of foundresses per nest was lowest in 1977 (3.82) and highest in 1980 (4.93; Fig. 1). The variation among years was significant but year explained only $2 \%$ of the variance in foundress association size (Fig. 1). Fewer than $5 \%$ of females nested alone in any year while over $16 \%$ of females were queens of associations and over $73 \%$ of females were subordinates (Table 1). 

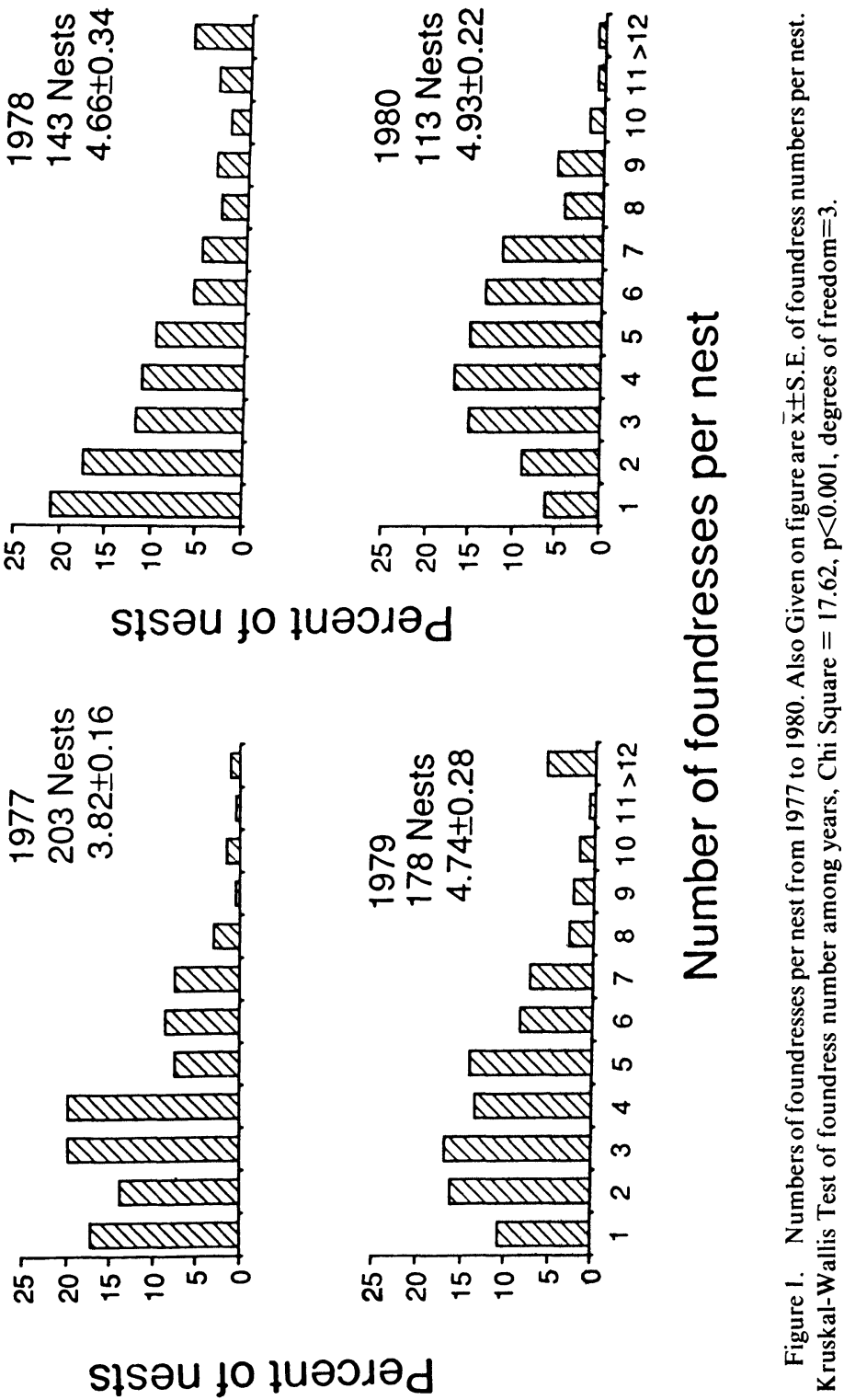

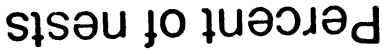


The number of available nestmates will limit the number of females on the same spring-time nest since foundresses nest cooperatively only with females that emerged from the same natal nest (Strassman 1979, 1983). Females marked on 105 nests in autumn survived to nest the following year (Fig. 2). Small numbers of natalnestmates put an upper limit on association size since a new nest can have no more foundresses than are available among surviving natal nestmates (Fig. 2). Therefore available nestmates can be viewed as a factor that limits number of females associating on a new nest. However, even females from large groups of natal nestmates often nested in groups of 2 or 3 foundresses.

The largest groups of foundresses are formed when females re-use their natal nest. Nests can be re-used in 2 ways. The actual cells can be re-used, or the nest can form a base for a new protruding nest that will be built on the cells of the original nest (Fig. 3). Included in the study were 20 re-used nests and 6 protruding nests. Protruding and re-used nests combined averaged $7.57 \pm$ S.E. $1.2(\mathrm{~N}=24)$ foundresses per nest while new nests averaged $4.34 \pm$ S.E. $0.12(\mathrm{~N}=$ 608 ) foundresses per nest. Thus re-used nests had significantly more found resses per nest (ANOVA, $\mathrm{P}<0.0001$ ). However, re-use status of the nest (re-used or new) explained only $4 \%$ of the variance in foundress association size.

Since foundresses meet their natal nestmates at the natal nest, multiple foundress nests are often begun close to the natal nest site. In $P$. annularis, nests with more foundresses were significantly closer to the natal nest than were nests with fewer foundresses (Fig. 4). Distance from the natal nest explained $8 \%$ of the variance in foundress numbers in 1977 and $12 \%$ in 1978.

Colonies of $P$. annularis have very high survival rates. Over $60 \%$

Table 1. Percent of foundresses that are group queens, group subordinates and solitary queens.

\begin{tabular}{|c|c|c|c|c|c|}
\hline Year & \# Nests & $\begin{array}{c}\# \\
\text { Found resses } \\
\end{array}$ & $\begin{array}{c}\% \\
\text { Group Queen } \\
\text { Foundresses }\end{array}$ & $\begin{array}{c}\% \\
\text { Subordinate } \\
\text { Foundresses }\end{array}$ & $\begin{array}{c}\% \\
\text { Solitary } \\
\text { Foundresses }\end{array}$ \\
\hline 1977 & 203 & 775 & 22 & 74 & 4 \\
\hline 1978 & 143 & 667 & 17 & 78 & 5 \\
\hline 1979 & 178 & 845 & 19 & 79 & 2 \\
\hline 1980 & 113 & 557 & 19 & 80 & 1 \\
\hline
\end{tabular}


of colonies in all years survived to produce workers. Of the surviving colonies, over $65 \%$ survive to produce reproductives, numbering on average 21 to 43 depending on the year (Table 2). Colonies where any females survived the winter were represented by on average 10 to 21 females divided among 2 or 3 nests in the new year (Table 2).

Table 2. Nest survival and reproduction

\begin{tabular}{|c|c|c|c|c|}
\hline & Year & $\overline{\mathrm{X}}$ & S.E. & $\begin{array}{l}\text { Number } \\
\text { of Nests }\end{array}$ \\
\hline $\begin{array}{l}\text { Proportion of nests surviving } \\
\text { to worker emergence }\end{array}$ & $\begin{array}{l}1977 \\
1978 \\
1979\end{array}$ & $\begin{array}{l}0.62 \\
0.75 \\
0.76\end{array}$ & $\begin{array}{l}0.04 \\
0.04 \\
0.03\end{array}$ & $\begin{array}{l}152 \\
104 \\
156\end{array}$ \\
\hline $\begin{array}{l}\text { \# Pupae produced given survival } \\
\text { to worker emergence }\end{array}$ & $\begin{array}{l}1977 \\
1978 \\
1979 \\
1980\end{array}$ & $\begin{array}{r}5.08 \\
16.77 \\
17.90 \\
18.24\end{array}$ & $\begin{array}{l}0.56 \\
1.29 \\
1.20 \\
0.94\end{array}$ & $\begin{array}{r}83 \\
73 \\
112 \\
111\end{array}$ \\
\hline $\begin{array}{l}\text { Proportion of nests surviving } \\
\text { to produce reproductives, given } \\
\text { survival to worker emergence }\end{array}$ & $\begin{array}{l}1977 \\
1978 \\
1979\end{array}$ & $\begin{array}{l}0.66 \\
0.85 \\
1.0\end{array}$ & $\begin{array}{l}0.05 \\
0.04 \\
0\end{array}$ & $\begin{array}{l}94 \\
78 \\
41\end{array}$ \\
\hline $\begin{array}{l}\text { \# Gynes produced given survival } \\
\text { to produce reproductives }\end{array}$ & $\begin{array}{l}1976 \\
1977 \\
1978 \\
1979\end{array}$ & $\begin{array}{l}32.63 \\
21.59 \\
41.87 \\
42.92\end{array}$ & $\begin{array}{l}4.32 \\
6.76 \\
6.17 \\
5.95\end{array}$ & $\begin{array}{l}56 \\
56 \\
30 \\
36\end{array}$ \\
\hline $\begin{array}{l}\text { Proportion nests surviving to } \\
\text { produce gynes that have at } \\
\text { least } 1 \text { survive to next year }\end{array}$ & $\begin{array}{l}1977 \\
1978 \\
1979\end{array}$ & $\begin{array}{l}0.71 \\
0.92 \\
0.83\end{array}$ & $\begin{array}{l}0.08 \\
0.08 \\
0.06\end{array}$ & $\begin{array}{l}34 \\
13 \\
35\end{array}$ \\
\hline $\begin{array}{l}\text { \# Gynes per nest surviving to } \\
\text { following spring given at least } \\
1 \text { survives }\end{array}$ & $\begin{array}{l}1977 \\
1978 \\
1979\end{array}$ & $\begin{array}{r}10.77 \\
20.64 \\
9.83\end{array}$ & $\begin{array}{l}2.07 \\
3.90 \\
1.54\end{array}$ & $\begin{array}{l}26 \\
14 \\
29\end{array}$ \\
\hline $\begin{array}{l}\text { Propostion gynes per nest } \\
\text { surviving to spring given } \\
\text { at least } 1 \text { survives }\end{array}$ & $\begin{array}{l}1977 \\
1978 \\
1979\end{array}$ & $\begin{array}{l}0.34 \\
0.50 \\
0.26\end{array}$ & $\begin{array}{l}0.04 \\
0.07 \\
0.03\end{array}$ & $\begin{array}{l}24 \\
14 \\
29\end{array}$ \\
\hline $\begin{array}{l}\text { \# New nests built given at } \\
\text { least one new nest }\end{array}$ & $\begin{array}{l}1977 \\
1978 \\
1979\end{array}$ & $\begin{array}{l}2.52 \\
3.36 \\
3.28\end{array}$ & $\begin{array}{l}0.25 \\
0.50 \\
0.44\end{array}$ & $\begin{array}{l}25 \\
14 \\
29\end{array}$ \\
\hline
\end{tabular}

Foundress number is a major determinant of nest success. Nests that were attended by fewer numbers of foundresses were much more likely to fail (Table 3, Figs. $5 \& 6$ ). Single-foundress nests were particularly vulnerable. Only about $20 \%$ of such nests survived to 


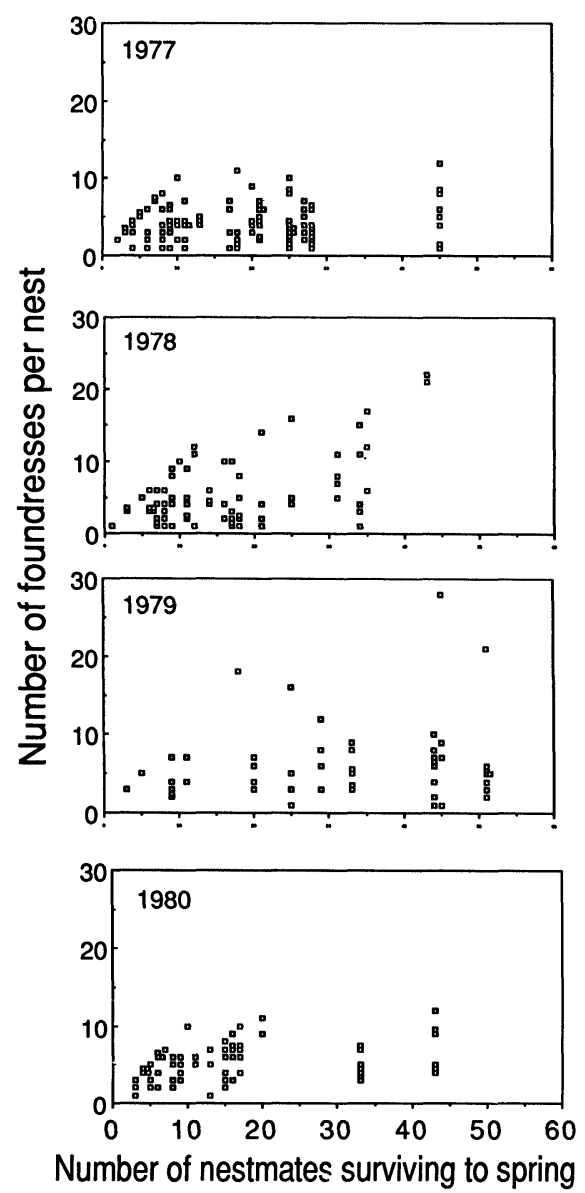

Figure 2. Numbers of foundresses per nest in spring as a function of numbers of nestmates available which is the number of females marked on the same natal nest the previous autumn that survived to spring. Total nests where females were marked the previous autumn are 33 in 1977, 29 in 1978, 13 in 1979 and 30 in 1980 (to match figure, years are given for spring nests, so year of marking is previous year). Correlations are not given because all data points are not independent, most natal nests having started multiple new nests. Even if average foundresses per new nest were used, a correlation would still be suspect because one will be forced by the upper limit that the number of foundresses available ( $x$ axis) imposes on foundresses per new nest (y axis). 


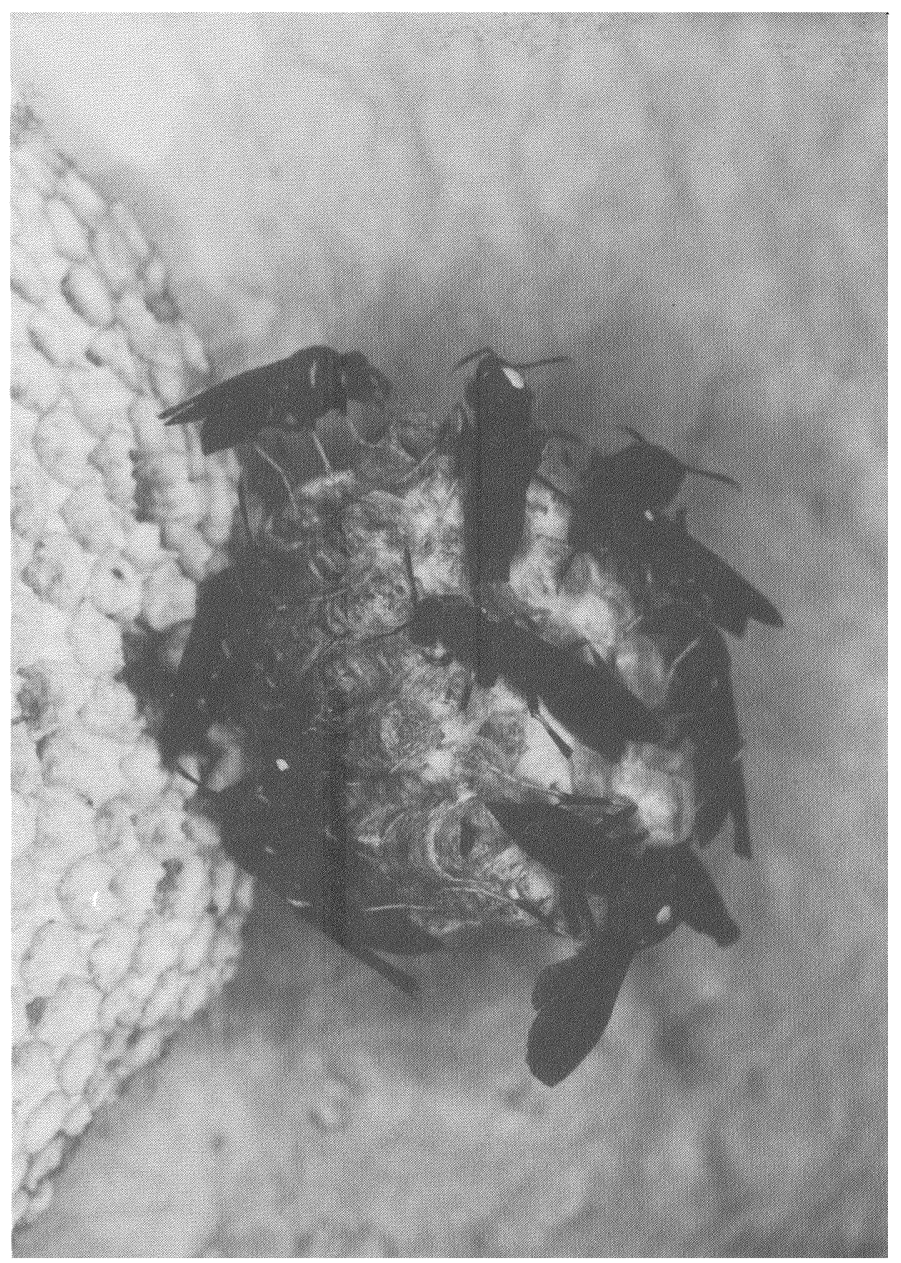


Table 3. Numbers of foundresses on nests surviving to produce reproductives and failing nests.

\begin{tabular}{|c|c|c|c|c|c|c|c|}
\hline \multirow[b]{2}{*}{ Year } & \multicolumn{3}{|c|}{ Surviving Nests } & \multicolumn{3}{|c|}{ Failing Nests } & \multirow[b]{2}{*}{$\mathrm{p}^{*}$} \\
\hline & Mean & S.E. & $\mathbf{N}$ & Mean & S.E. & $\mathbf{N}$ & \\
\hline 1977 & 4.7 & 0.29 & 62 & 3.0 & 0.21 & 90 & .0001 \\
\hline 1978 & 5.5 & 0.53 & 66 & 2.3 & 0.59 & 36 & .0001 \\
\hline 1979 & 6.0 & 0.56 & 35 & 3.4 & 1.0 & 20 & .0001 \\
\hline
\end{tabular}

*t-test

worker emergence while nests with 4 or more foundresses had better than an $80 \%$ chance of surviving the same period (Fig. 5; Table 4). Foundress number explained half the variance in pupae produced at worker emergence in all years except 1977 (including only nests still extant at this point; Table 4, Fig. 5). An April flood followed by a summer drought made 1977 an especially poor year. In that year nests of fewer than four foundresses that were not flooded averaged only $20 \%$ success $(\mathrm{N}=78$ nests) whereas nests of 4 or more foundresses averaged $62 \%$ success $(\mathrm{N}=74$ nests; Fig. 6$)$. The impact of additional foundresses was similar though not so pronounced for 1978 and 1979 (Fig. 6). The regression of gyne number on number of foundresses was not significant in any year (Fig. 6). So the main impact of multiple foundresses is on nest success, and not variation in reproductive output given that the nest is successful (Table 3).

If a nest is usurped by unrelated females, then the original foundresses do not have any reproductive success. Larger foundress associations may also be more successful at deterring usurpers. In 1977 nests that were usurped averaged 5.17 foundresses (S.E. = $0.81, \mathrm{~N}=12$ ) while nests that were not usurped averaged 4.17 foundresses (S.E. $=0.26, \mathrm{~N}=93$ ) which is not a significant difference (ANOVA, $p>0.1$ ). Thus additional foundresses do not help protect the nest from usurpation.

\section{Discussion}

Large foundress groups such as those reported here are common in P. annularis. Rau $(1928,1929,1940)$ found nests of 1 to 6 foundresses per nest in Missouri. Krispyn (1979) found $3.7 \pm 2.1$ foundresses per nest $(\mathrm{N}=83$ nests) in Athens, Georgia. Wenzel (pers. comm.) found $2.6 \pm 1.9$ foundresses per nest $(\mathrm{N}=30$ nests) in 


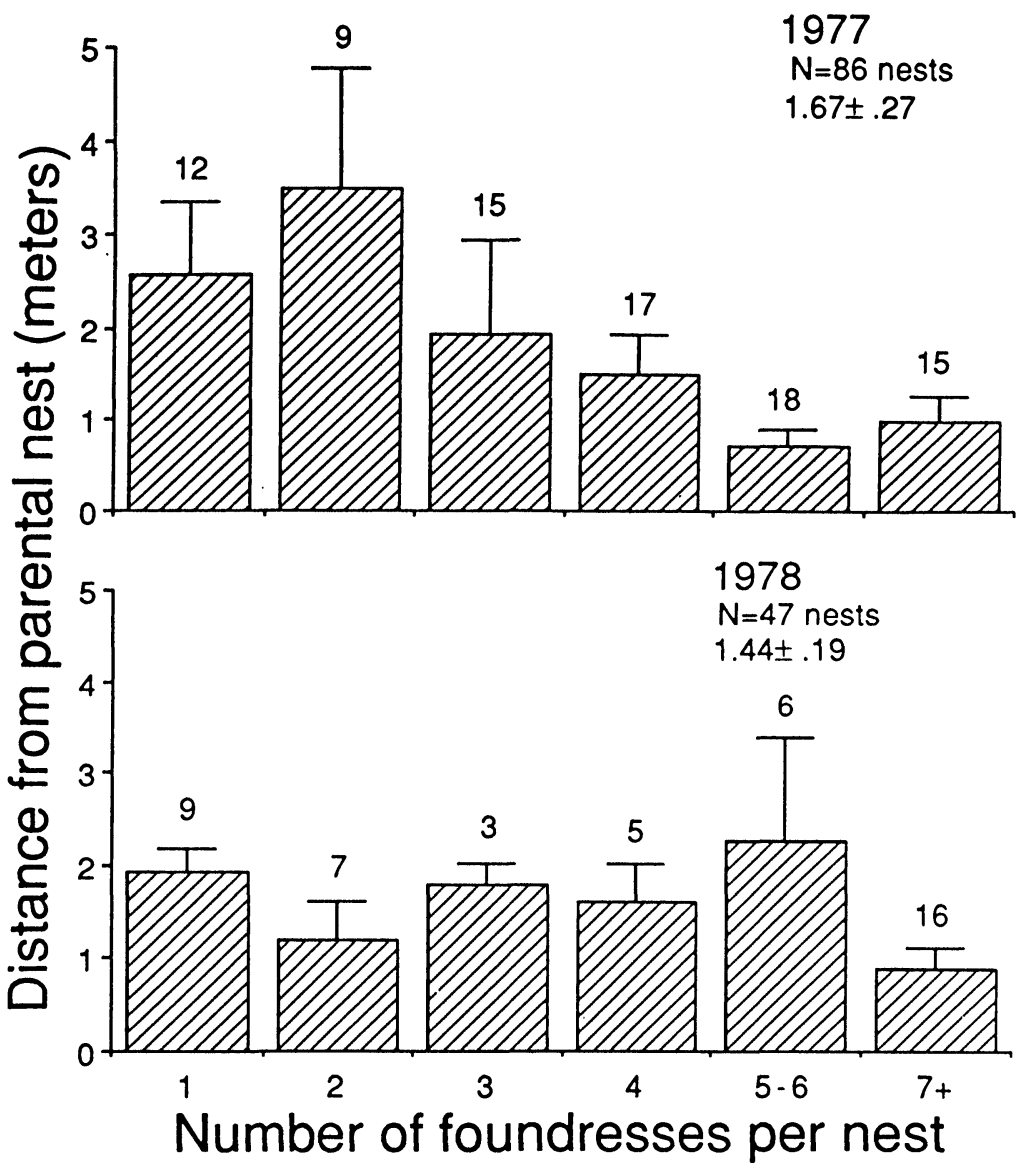

Figure 4. Distance from parental nests in meters as a function of the number of foundresses. The regression equation of foundress number $(F)$ on distance to the natal nest (D) is: $F=4.74 \pm 0.31-0.27 \pm 0.10 \mathrm{D}$, degrees of freedom $=1,84$ and $\mathrm{p}<0.01$ for 1977 and $\mathrm{F}=8.50 \pm 1.2-1.5 \pm 0.61 \mathrm{D}$, degrees of freedom $=1,44$ and $\mathrm{p}<0.02$ for 1978 .

Lawrence, Kansas. Foundress association sizes in the population I studied are the largest of all those reported. Few other species of Polistes have larger foundress associations than $P$. annularis (Hughes 1987). The average foundress association size ( $\overline{\mathrm{x}} \pm$ S.E.) of $P$. annularis is exceeded only by $P$. omissus in Pisa, Italy (5.2 \pm 4.9 , 


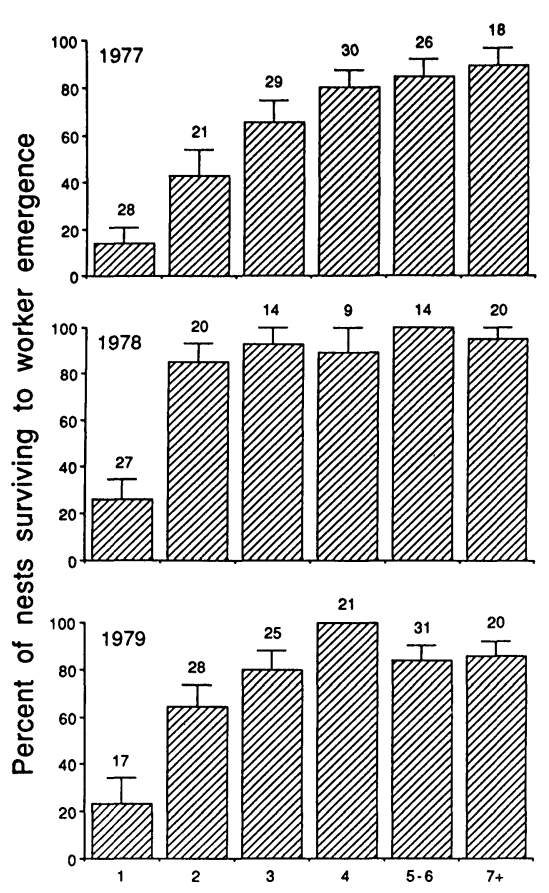

Number of foundresses per nest

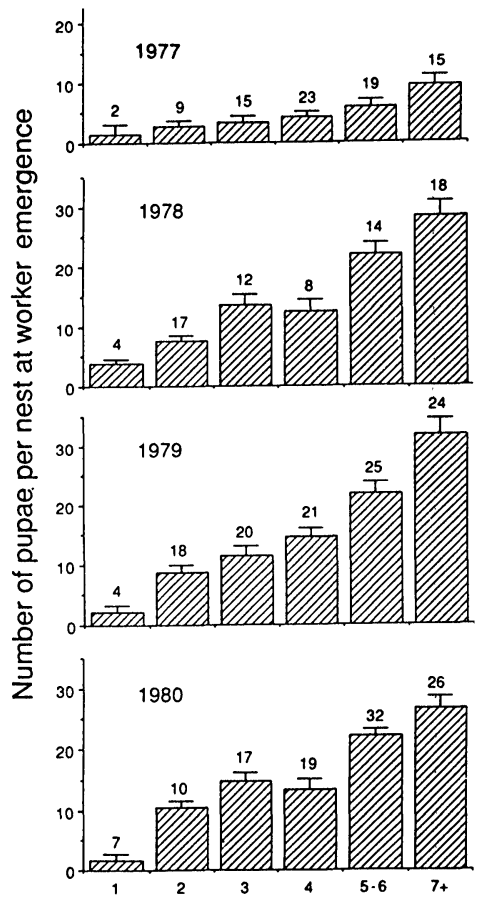

Number of foundresses per nest

Figure 5. Nest survival to worker emergence, and reproductivity to that point for surviving nests measured in pupae as a function of numbers of foundresses. The bar represents the mean, the line is the standard error, and the number over the standard error is the number of nests examined.

Pardi 1947), P. carolina in Kirkwood, Missouri (6.0 \pm 7.4 , Rau 1931), P. canadensis in Panama (6.1, Pickering 1980) and P. canadensis in Cali, Colombia (4.9, West-Eberhard 1969).

Though additional foundresses increase the productivity of the colony and its chances for survival, the inclusive fitness of subordinate foundresses is not usually higher than it would be if they nested alone (Queller \& Strassman 1988). Estimated inclusive fitness for subordinates was lower than that for lone females in 1977, and higher than lone females for subordinates in groups of 2 or 3 (Queller \& Strassman 1988). In other group sizes subordinates had inclusive fitnesses that ranged from $30 \%$ to $69 \%$ that of lone females. In fact all subordinates in 1977 and $86 \%$ of subordinates in 
1978 joined groups in which they could expect a loss of inclusive fitness as compared to nesting alone.

Since the inclusive fitness of subordinates is usually lower than that of lone foundresses, it is not clear why these females do not leave the group to establish nests on their own. In many species results such as these might be explained by frequent early failure of singly-founded nests which are undetected, and conceal the disadvantages of solitary nesting. But all nests were visible on the cliff face, and failure rates of nests with all numbers of females on them were accurately tabulated from the beginning of the season. Errors in the relatedness calculations or in the division of egg laying could increase the inclusive fitness of subordinates, but not enough to make joining pay in most circumstances.

It is possible that females remain in groups because they are making the best of a bad job, and are either incapable of laying eggs, or have no good nesting sites to use. However, neither of these is likely to apply to P. annularis (Queller \& Strassmann 1988, 1989; Strassman \& Queller 1989). Small size may be an indication of poor competitive ability, but there was no evidence that smaller females were more likely to join larger groups (Sullivan \& Strassmann 1984). Females deprived of winter honey had lowered survival and built smaller nests than undeprived controls, and yet these females did not begin new nests in larger groups (Strassman 1979). Nesting sites under the overhang were not clearly limited-it appeared that nests could be more densely packed together since nests density did

Table 4. Regression equations of pupae at worker emergence and gynes at end of season on foundress number.

\begin{tabular}{|c|c|c|c|c|c|}
\hline Year & $\begin{array}{c}\text { \# of } \\
\text { Foundresses } \\
\pm \text { S.E. }\end{array}$ & $\begin{array}{c}\text { Intercept } \\
\pm \text { S.E. }\end{array}$ & $\begin{array}{c}\text { Degrees } \\
\text { of Freedom }\end{array}$ & $\mathrm{r}^{2}$ & $\mathrm{p}$ \\
\hline \multicolumn{6}{|c|}{ A. Pupae at worker emergence given survival to worker emergence } \\
\hline 1977 & $0.99 \pm 0.24$ & $0.51 \pm 1.21$ & 1,81 & .18 & .0001 \\
\hline 1978 & $1.76 \pm 0.21$ & $7.38 \pm 1.47$ & 1,71 & .49 & .0001 \\
\hline 1979 & $3.26 \pm 0.31$ & $2.34 \pm 1.70$ & 1,110 & .50 & .0001 \\
\hline 1980 & $2.91 \pm 0.29$ & $4.08 \pm 1.58$ & 1,109 & .47 & .0001 \\
\hline \multicolumn{6}{|c|}{ B. Gynes at end of season given survival to end of season } \\
\hline 1977 & $-0.47 \pm 1.19$ & $23.9 \pm 6.3$ & 1,54 & .00 & .68 \\
\hline 1978 & $0.21 \pm 1.4$ & $39.6 \pm 10.4$ & 1,25 & .00 & .88 \\
\hline 1979 & $2.3 \pm 1.9$ & $29.6 \pm 12.7$ & 1,33 & .04 & .22 \\
\hline
\end{tabular}


not have an effect on either foundress number or nests reproductive success. In years with fewer total nests on the cliff face, foundress associations were not correspondingly smaller, which also indicates a lack of competition for nest sites (Queller \& Strassman 1988).

Constraints operating on foundresses appear more likely to force an upper limit on foundress association size than to force a lower limit. Foundress numbers are higher from nests with many natal nestmates and on nests that are close to the natal nest or are re-uses of the natal nest. These constraints limit the total number of foundresses per nest; without them foundress associations might be even larger. The foundresses choose not to disperse, and it appears, to nest in large groups with natal nestmates. These colonies are usually highly successful.

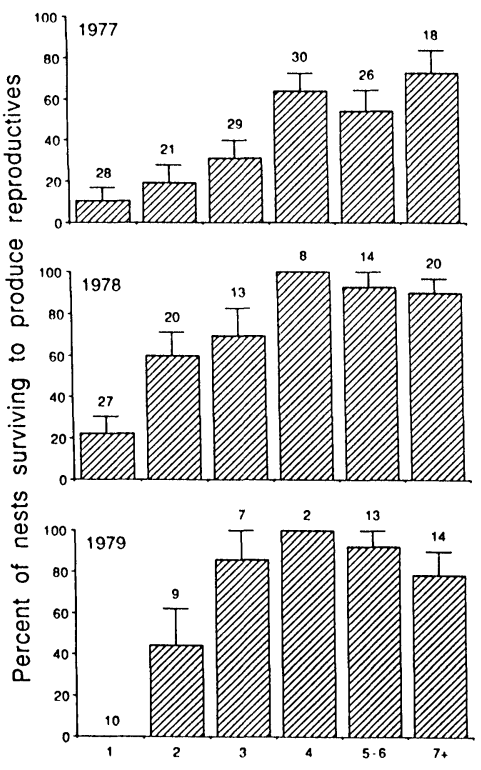

Number of foundresses per nest

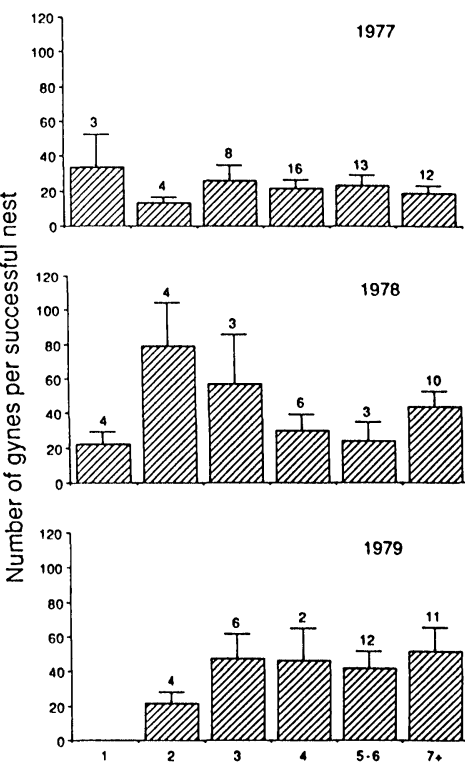

Number of foundresses per nest

Figure 6. Nest survival and reproductivity for surviving nests measured in gynes produced at the end of the season, as a function of numbers of foundresses. The bar represents the mean, the line is the standard error, and the number over the standard error is the number of nests examined. 


\section{SUMMARY}

Females of the social wasp, Polistes annularis, begin nests in groups averaging 4.5 mated foundresses that are among the largest such groups reported for Polistes. Number of foundresses per nest is correlated with distance from the natal nest, number of overwintering natal nestmates, and re-use of the natal nest. Larger groups of foundresses build larger nests that contain more pupae at the time of worker emergence, and are more likely to survive to produce reproductives. Highly social behavior in this species appears to be the result of an extreme reluctance on the part of individual females to disperse far from the natal nest site where most nests are successful.

\section{ACKNOWLEDGMENTS}

For help with nest censuses I thank Diana Crowell, Scott Davis, Robert Matlock, Dana Meyer, Beverly Strassmann, Anita Thomas and Richard Thomas. Larry Gilbert, Alan Templeton and John Smiley provided much advice during the field study. I thank Colin Hughes, Dave Queller and Jim Carpenter for comments on the manuscript. Partial support was provided by NIH 5-T32-GM-07126 and NSF BSR86-05026.

\section{Literature Cited}

Hamilton, W. D. 1964a. The genetical evolution of social behaviour, I. J. Theor. Biol., 7: 1-16.

Hamilton, W. D. 1964b. The genetical evolution of social behaviour, II. J. Theor. Biol., 7: 17-52.

KLAHN, J. E. 1979. Philopatric and nonphilopatric foundress associations in the social wasp, Polistes fuscatus. Behav. Ecol. Sociobiol. 5: 417-424.

KRISPYN, J. W. 1979. Colony productivity and survivorship of the paper wasp, Polistes annularis. Ph. D. Thesis, Univ. Georgia, Athens, Georgia.

Metcalf, R. A. ANd G. S. Whitt. 1977. Relative inclusive fitness in the social wasp, Polistes metricus. Behav. Ecol. Sociobiol. 2: 353-360.

Noonan, K. M. 1981. Individual strategies of inclusive fitness maximizing in Polistes fuscatus foundresses. In: Natural selection and social behavior: recent research and new theory. (R. D. Alexander \& D. W. Tinkle, eds.) pp. 18-44. Chiron Press, New York.

Pardi, L. 1942. Richerche sui Polistini. Bolletino del'Istituto di Entomologia dell'Universita di Bologna 14: 1-104.

Pardi, L. 1947. Ricerche sui polistini 9. Poliginia eccezionale in Polistes (Leptopolistes) omissus Weyrauch. Processi Verbali 54: 1-7. 
Pickering, J. 1980. Sex ratio, social behavior and ecology in Polistes (Hymenoptera, Vespidae), Pachysomoides (Hymenoptera, Ichneumonidae) and Plasmodium (Protozoa, Haemosporida). Ph.D. Thesis, Harvard University, Cambridge, Mass.

Queller, D. C., And J. E. Strassmann. 1988. Reproductive success and group nesting in the paper wasp, Polistes annularis. In Reproductive Success: Studies in Selection, Adaptation, and Demography in Contrasting Systems. (T. H. Clutton-Brock ed.) pp 76-96, University of Chicago Press, Chicago.

Queller, D. C., AND J. E. Strassmann. 1989. Measuring inclusive fitness in social wasps. pp. 103-122. In The Genetics of Social Evolution. (M. Breed \& R. Page, eds.) Westview Press, Boulder, Colorado.

Rau, P. 1928. Autumn and spring in the life of the queen Polistes annularis and $P$. pallipes. Bull. Brook. Ent. Soc. 23: 230-235.

1929. The habitat and dissemination of four species of Polistes wasps. Psyche 10: 191-200.

1931. The nests and nesting sites of four species of Polistes wasps. Bull. Brook. Entom. Soc. 26: 111-119.

1940. Cooperative nest founding by the wasp, Polistes annularis Linn. Ann. Ent. Soc. Amer. 33: 617-620.

Strassmann, J. E. 1979. Honey caches help female paper wasps (Polistes annularis) survive Texas winters. Science, 204: 207-209.

1981. Wasp reproduction and kin selection: reproductive competition and dominance hierarchies among Polistes annularis foundresses. Fla. Entomol., 64: $74-88$.

1983. Nest fidelity and group size among foundresses of Polistes annularis (Hymenoptera: Vespidae). J. Kans. Entomol. Soc. 56: 621-634.

\& D. C. Queller. 1989. Ecological determinants of social evolution. pp. 81-101. In: The genetics of social evolution. (M. Breed \& R. Page, eds.) Westview Press, Boulder, Colorado, 213 pages.

Sullivan, J. D., and J. E. Strassmann. 1984. Physical variability among nest foundresses in the polygynous social wasp, Polistes annularis. Behav. Ecol. Sociobiol., 15: 249-256.

West-Eberhard, M. J. 1969. The social biology of polistine wasps. Misc. Publ. of the Museum of Zool, U. of Michigan, 140: 1-101. 

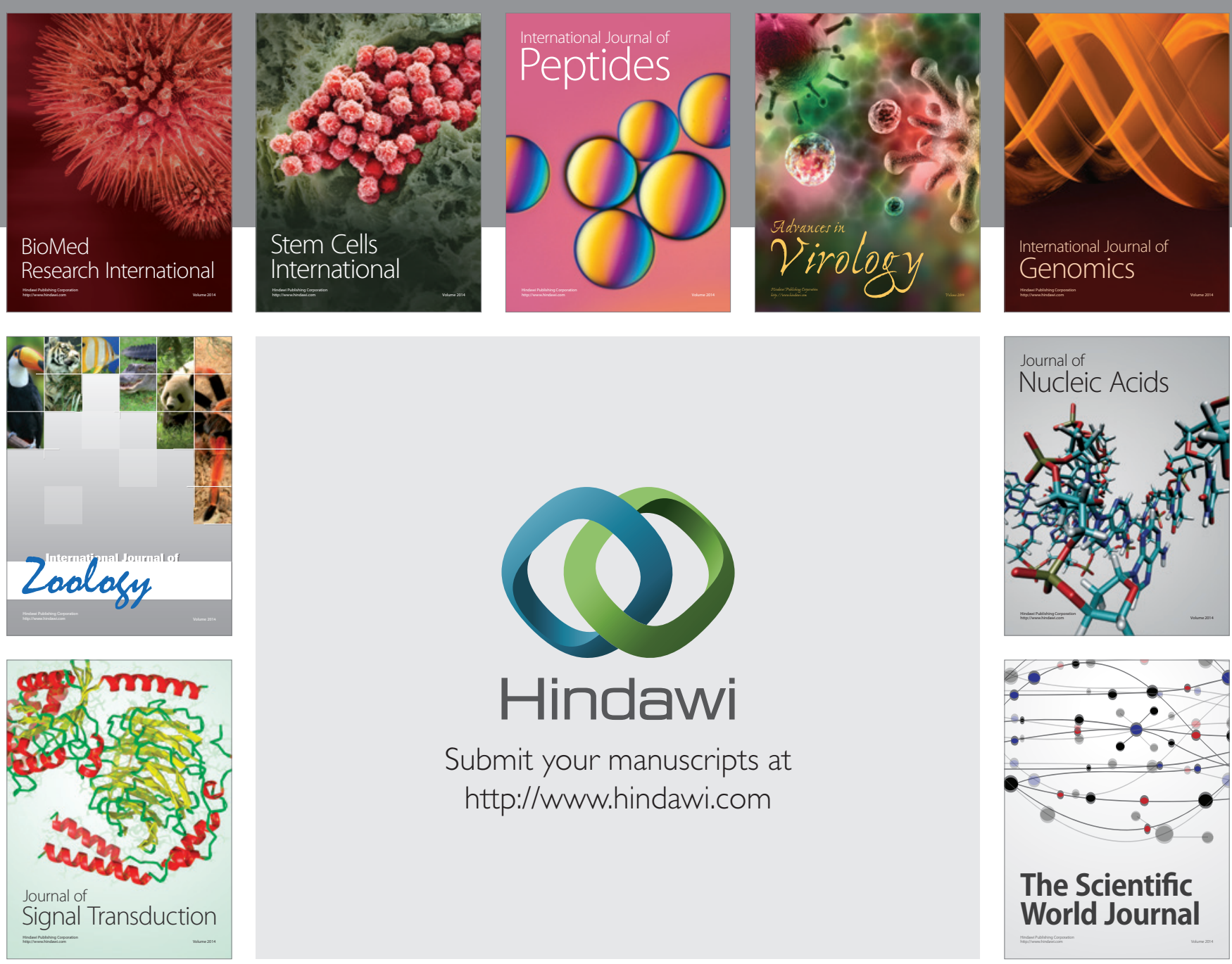

Submit your manuscripts at

http://www.hindawi.com
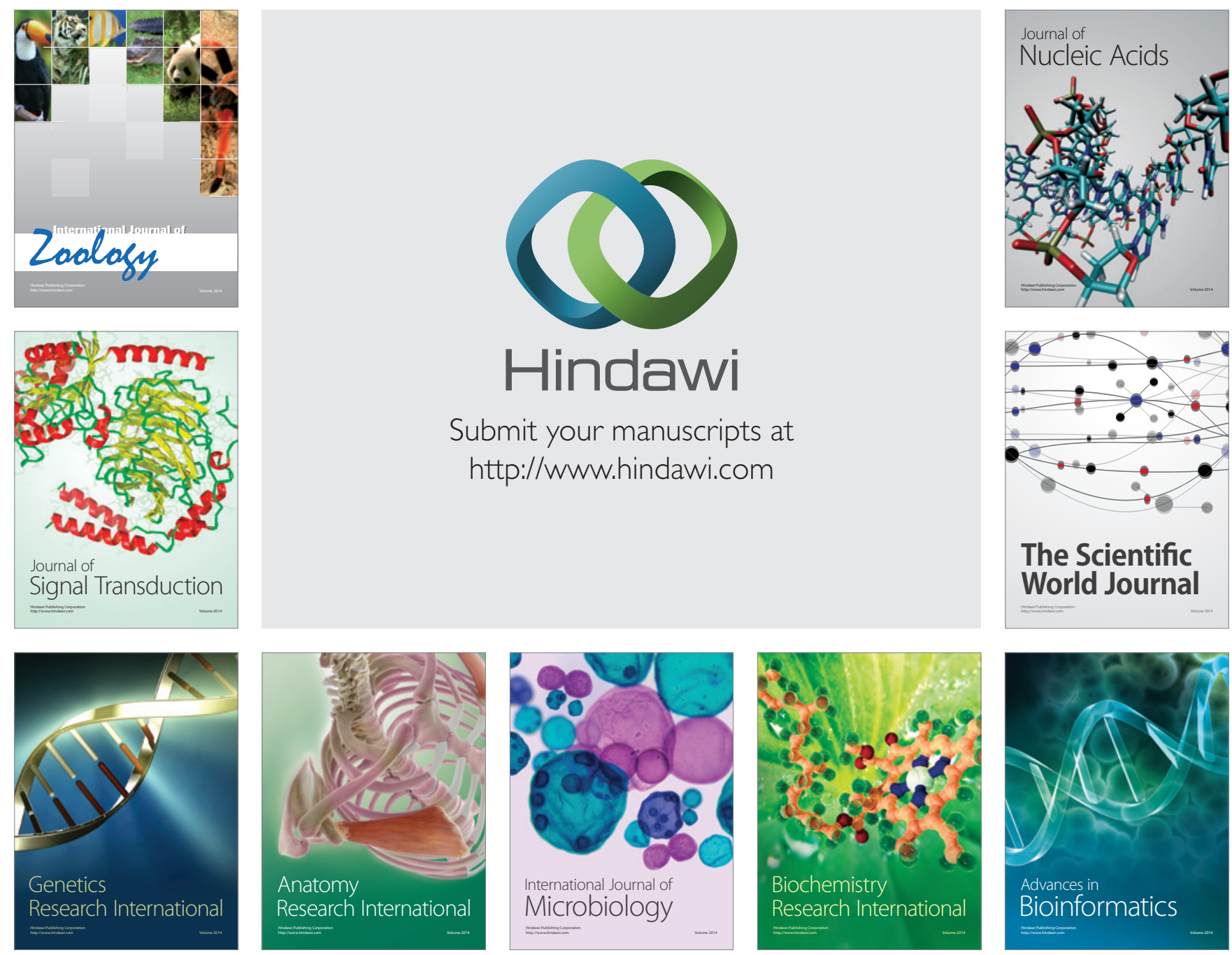

The Scientific World Journal
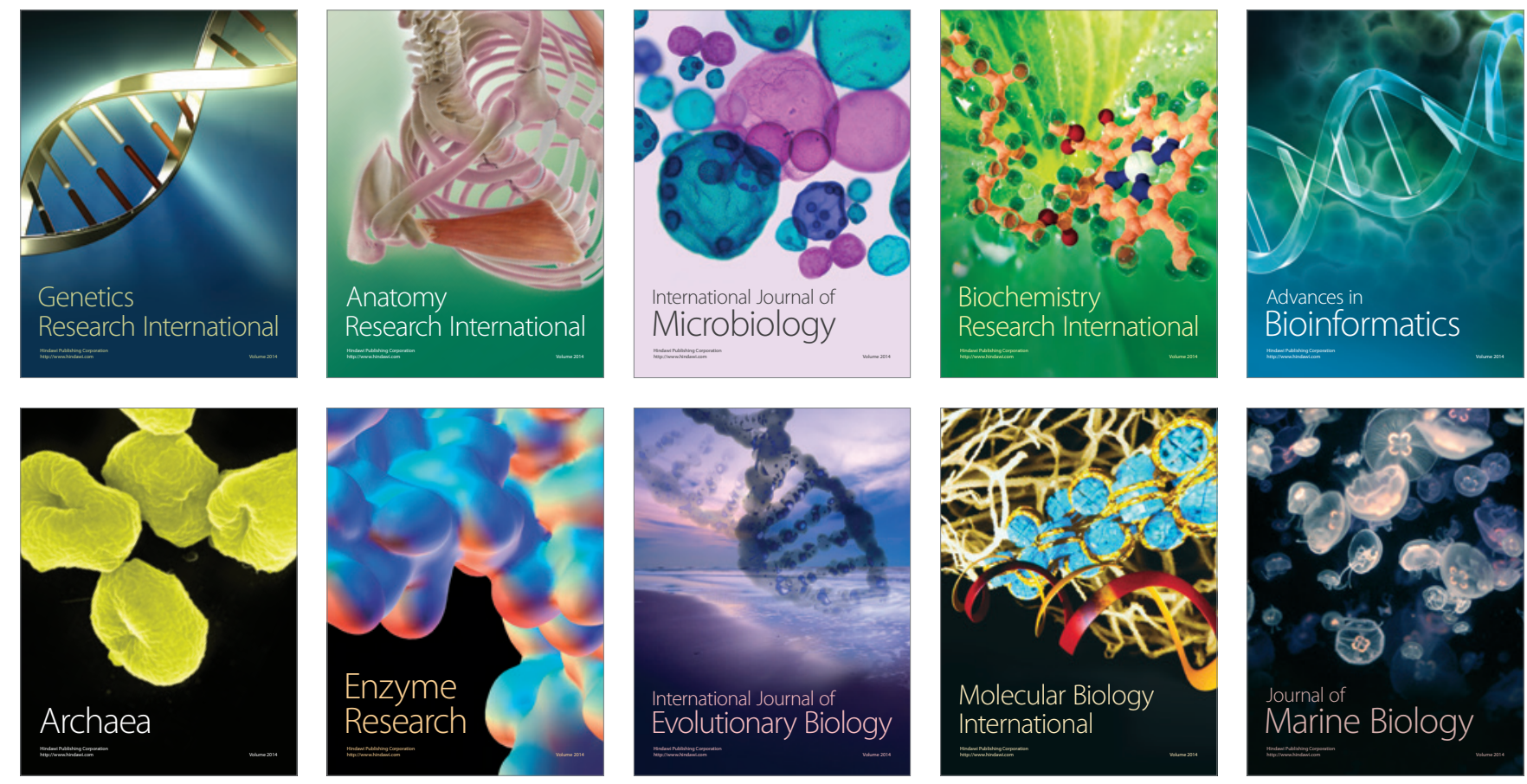